\title{
Influence of stakeholders' perception on value creation and measurement: the case of football clubs
}

\author{
Igor Perechuda \\ Faculty of Management and Social Communication, Institute of Entrepreneurship, \\ Jagiellonian University, Kraków, Poland, and \\ Tomaž Čater \\ Management and Organisation, School of Economics and Business, \\ University of Ljubljana, Ljubljana, Slovenia
}

\begin{abstract}
Purpose - The presented study aims to identify and classify the value factors that influence the value of football clubs from the stakeholder perspective, while also discussing how these factors can affect the choice of valuation methods. The paper considers how value should be measured from the perspective of stakeholders. Research focuses on clubs embedded deeply in a wide interrelated network of stakeholders.

Design/methodology/approach - A mixed research approach was established in order to obtain a more holistic understanding of value creation, value factors and measurement. The research builds on observational study with a mix of retrospective longitudinal study of Polish men's football clubs and interviews with stakeholders, which are then triangulated as part of a critical discussion on valuation methods.

Findings - The results show the most significant value factors determined by the stakeholders. The study discusses which performance and value measures should be used to measure value for the stakeholders of football clubs. Intellectual capital methods and asset-based methods should definitely be relied on as part of measuring the performance of football clubs within the stakeholders' network. All findings suggest the use of the multivariate valuation method in accordance with previous research.

Originality/value - The classified key value factors enable the management of football clubs to properly manage stakeholder relationships and address various stakeholders' concerns in a sustainable way. The paper proposes a research process, which may also be implemented in other studies in the non-profit sector and contributes to the literature in the fields of sports management.
\end{abstract}

Keywords Stakeholders, Performance measurement, Football, Valuation, Poland

Paper type Research paper

\section{Introduction}

The aim of this paper is to develop a value measurement of football clubs based on stakeholders' perspective. The study used the case of Polish men's football to reach its aim. This paper relies on different sources of information that are triangulated in the final step of the study in order to increase its validity. The research steps are as follows:

Step 1: Conceptualisation of the problem (described in sections 1, 2 and 3 of this paper)

Step 2: Translation of the problem into specific research questions (section 3)

Step 3: Analysis of football clubs' financial data (section 4)

Step 4: Interviews concerning value factors (sections 3 and 5)

Step 5: Triangulation of the collected data and discussion on valuation methods and their utility from the perspective of football club stakeholders (sections 6 and 7).
Influence of stakeholders' perception on

value
Received 29 March 2021 Revised 26 November 2021 Accepted 30 November 2021 


\subsection{Stakeholders and value}

The value concept in the study is based on the bundle of benefits that the stakeholders will be receiving. The research problem touches on accounting theories about the measurement of financial and non-financial performance. Stent and Dowler (2015) and Parker (2005) distinguish two main groups of such theories. The first group treats social and environmental accounting as complementary to conventional accounting (e.g. stakeholder theory, economic agency theories, decision-usefulness theories, legitimacy theory, accountability theory). The second group focuses on the role played by information in the relationships between the organisation and society (e.g. political economy accounting theory, deep green ecological perspectives, eco-feminist approach, communitarian-based theories). Our study relies on stakeholder theory as a tool to thoroughly investigate football clubs. According to Freeman and McVea (2001), a stakeholder is an individual or group with the chance to influence an organisation's achievement of its objectives or can be influenced by the organisation to achieve its goals. According to the stakeholder view of the firm (Clarkson, 1995; Post et al., 2002), a company can endure if it is able to maintain sustainable and durable relationships with all of its stakeholders. Hence, these relationships are "the ultimate sources of organizational wealth" (Post et al., 2002, p. 8). In stakeholder theory, stakeholder pressure forces organisations to implement values in their actions they consider important. Therefore, the creation of value for the stakeholders is a goal of the organisation, while stakeholders are meant to provide the resources needed for proper functioning. Consequently, if an organisation wishes to improve its results, it should skilfully balance the needs of its stakeholders (Clarkson, 1995).

The stakeholder theory also applies to the fields of public, social and sports organisations, including football clubs (Sanchez et al., 2017). Moreover, it could be developed a step further. Freeman and McVea (2001) limited the concept to the input and output of stakeholders, yet in the example of football clubs we can observe the effects of synergy and deep interrelations (Figure 1). The influence of stakeholders approach was already studied in the case of nonprofit sports organisations and national sports federations and is pointed as an important key to understand sports organisations' activities (Thompson and Parent, 2021; Ferkins and Shilbury, 2015). The relationships among the stakeholders of football clubs are considerably more intertwined than any simple relationship between employee, client, local citizen and company. Polish football clubs are an exemplification of deep stakeholder influence. Figure 1 presents the structure of the main network of external stakeholders of a football club in Poland along with the types of influences. The figure was prepared based on observations and collected data concerning the legal and trade relations between the entities described on the basis of a concept from Senaux (2008) and a study from Gerke and Wäsche (2019) on football networks.

A case study of the English Premier League (EPL) (Castro-Martinez and Jackson, 2014) stated that the value created by football clubs is created collaboratively with the stakeholders and called it creating shared value. Important input into discussion about value co-creation in sports management was provided by Woratschek et al. (2014) an their "sport value framework". They noticed that in case of team sports events, value is always co-created by many different stakeholders. And the role of firms, customers and other stakeholders is to integrate the resources of their specific networks to co-create value. Moreover, sports firms create value propositions mainly in the configuration of a value network as presented on Figure 1. Football clubs in Poland accomplish social objectives by engaging in certain activities (Pawlak and Smoleń, 2015). In the case of football clubs, we can see that a network (Figure 1) cooperating together creates a common good for different stakeholder types. In some cases, this is a direct result of legal relations, when local government institutions are co-owners of the club, while in other cases it is a result of relations as viewed from the managerial perspective of stakeholder theory. Therefore, to properly approach the notion of 
$\longrightarrow$ external influence
$\ldots . . . . \rightarrow$

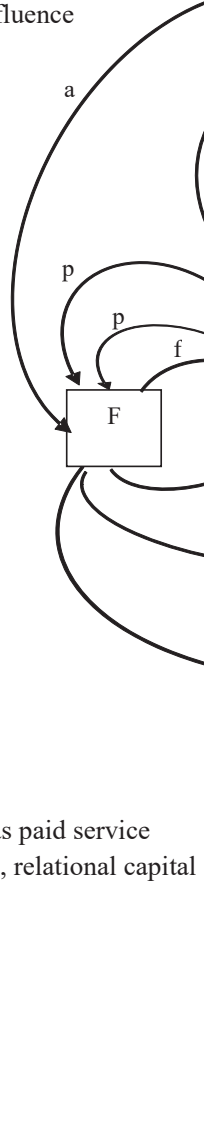

Type of influence:

$\mathrm{p}$ - promotion

$\mathrm{sr}-$ sports results

$\mathrm{a}$ - advertisement as paid service

$\mathrm{pr}$ - public relations, relational capital

$\mathrm{s}-$ sponsoring

i - image

$\mathrm{f}-$ financial

e-emotions

$\mathrm{r}$ - regulation

$\mathrm{b}$ - business lobby

$\mathrm{k}$ - knowledge
Influence of stakeholders' perception on value
Entities:

FC - football club

$\mathrm{F}$ - firms, business organisations

$\mathrm{M}-$ media organisations (media

houses, newspapers, radio etc.)

$\mathrm{Z}$ - football player

$\mathrm{S}$ - supporters, local community

$\mathrm{L}$ - local government

$\mathrm{O}$ - other organizations (sports associations, educational sector)

Source(s): Own elaboration based on Senaux (2008), Gerke and Wäsche (2019), Wagner et al. (2021)

Figure 1.

Network of a football club in Poland

value measurement in football clubs, the stakeholders of these clubs need to be analysed and included in the process, as mentioned by Sanchez et al. (2017), in order to show the importance of all stakeholder groups in football clubs.

\subsection{Gap in the sports valuation and performance literature}

Gaps exist in the literature concerning efficiency and valuation in the sports sector. While some research on the methods used to value football clubs in Europe exists, it is very limited with respect to the countries in Central and Eastern Europe. Most of the valuation discussion is based on very commercialised leagues, for example, the English Football League. It exclusively concentrates on the shareholder perspectives relevant to privately owned football clubs in England, France or Italy (Scelles et al., 2013, 2017, 2018). However, in Poland, one of the main shareholders of such clubs is local government. Moreover, most football clubs in 
Poland have negative financial results, which is why they need local government support. Further, football club research in Europe primarily deals with media value, football player value and the stock price of listed clubs (Callejo and Forcadell, 2006; Demir and Danis, 2011; Garcia del Barrio et al., 2016; Garcia del Barrio and Pujol, 2013; Leifheit and Follert, 2021; Garcia-del-Barrio, 2018), where it is suggested that a football player is both a specific asset and a human resource (Dobson et al., 2000; Morrow, 1996, 1997; Shareef and Davey, 2005; Perechuda, 2016; Lozano and Gallego, 2011). Garcia del Barrio et al. (2016) and Garcia-del-Barrio and Pujol (2021) propose a methodology for evaluating and rating the intangible talent of football players. Most of these studies were conducted in top European leagues in Spain, England, Germany, France and Italy, and included well-known football brands.

However, only a few authors have researched the phenomenon in Central and Eastern European (CEE) leagues, such as in Poland or Romania (Bednarz, 2014; Wyszynski, 2016; Roşca, 2012, 2014; Havran, 2014; Iconomescu, 2017; Novotny and Sciklin, 2011). Performance measurement research in sports clubs in CEE may therefore be considered underdeveloped. The reason for this may be the lower quality of football clubs and sports in general, the media as well as the relatively poor business results in the region of CEE. Only a small number of authors have considered sports clubs with less business efficiency and verified their performance measurement methods (Wyszynski, 2016; Novotny and Sciklin, 2011; Szymanski and Kuypers, 1999). In the field of sports business, authors have chiefly sought to identify financial strategies (Pawlak and Smoleń, 2015) or business models (Cyfert and Janicki, 2016) more than analyse their application to valuation and performance measures or the usefulness of financial and non-financial information. Additionally, another issue is in the case of football business: How is the intellectual capital valued in football? Is it based on the information in the financial statements, while it is also necessary to use non-financial information in such methods? Prior studies in other business areas suggest that non-financial performance measures are also relevant in the discussion on any valuation methods (Amir and Lev, 1996; Ittner and Larcker, 1998; Behn and Riley, 1999; Trueman et al., 2000, 2001; Nagar and Rajan, 2001; Simpson, 2010; Carlsson-Wall et al., 2016).

Defining and specifying performance in the sports business field is not easy because it is necessary to identify the evaluation criteria and factors affecting the performance (CarlssonWall et al., 2016). It is also necessary to determine which of these factors is the most significant. A football club's development depends on the sustainability of its stakeholder relationships: a club must consider and engage not only shareholders, employees and institutional/individual clients, but also public authorities, the local (or international, depending on the brand recognition) community and civil society, financial partners, sponsors and so forth. Nowadays, the quality, that is, the sustainability of stakeholder relationships, must be the guiding principle of a football club's strategy like it is for other business entities (Jabłoński and Jabłoński, 2016). There are still many issues related to stakeholders' dependency. Ma and Kurscheidt (2019) find that football in China (with its specific character and last reform (Peng et al., 2019)) also faces substantial governance problems caused by the divergence of goal setting, organisational inefficiencies and compliance issues. In this relational view of a football club, success and value cannot be measured in a narrow shareholder perspective but only by adopting a more holistic and comprehensive stakeholder framework. Clubs need appropriate systems to measure and control their behaviour in order to assess whether they are responding to stakeholder concerns effectively and to communicate and demonstrate the results they achieve. These new evaluation and reporting systems should seek to broaden, integrate and improve the traditional financial approaches to performance measurement and corporate valuation by 
ensuring that stakeholders' needs and requirements are duly taken into account (Perrini and Tencati, 2006; Plumley et al., 2017).

Most research here concerns the performance of sports clubs but is based on the very commercialised Premier League (Plumley et al., 2017). As an atypical enterprise, a football club has a wide group of stakeholders to which it provides benefits (Sanchez et al., 2017). In addition to functioning as an enterprise in the form of a joint-stock company, a football club often performs various social and public tasks. Further, creating benefits for the stakeholders touches on the existence of intangible and hard-to-measure values in the club, which is why it is necessary to properly identify and classify key value-creating factors of football clubs. The summary shown in Table 1 presents the main areas of the literature gaps concerning football clubs' performance.

\section{What is the problem with value of football clubs? Theoretical background}

The stakeholder network (Figure 1) determines the demand for financial and non-financial information (Freeman and McVea, 2001) in the process of measuring the value of a football club. A stakeholders' approach shows that the expectations of football club stakeholders are not directly monetary in nature for all of them. The financial condition of football clubs is paramount in their ability to deliver non-financial value to stakeholders, as a bad financial condition may lead them to focus on improving it and not enable them to deliver non-financial value to stakeholders A financial analysis of Polish football clubs and understanding how they function are fundamental for understanding the limitations that arise while applying methods to measure value.

The paper is partially embedded in the value-based management theory where the focus is on value indicators of the organisation, mostly financial ones, such as economic value added (EVA), market value added (MVA) and shareholder value added (SVA). Black et al. (1998) divide these measures into three groups. One of them includes value drivers which are described later in this paper (sales revenue, operating profit, asset investment, fiscal performance). Another group includes as EVA, MVA and others of a similar structure, which are considered to be superordinate to the rest. The final type of measures, subordinate to the

Research problems in the literature related to performance and valuation in football clubs are associated with

o Human resources topics (Dobson et al., 2000; Morrow, 1996, 1997; Shareef and Davey, 2005; Lozano and Gallego, 2011)

o Football clubs listed on the stock exchange or the shareholders' perspective (Callejo and Forcadell, 2006; Demir and Danis, 2011; Prigge and Tegtmeier, 2020)

o Marketing and media in football (Garcia del Barrio et al., 2016; Garcia-del-Barrio and Pujol, 2021; Garcia del Barrio and Pujol, 2013)

o The economic perspective (Dermit-Richard et al., 2019; Terrien and Andreff, 2020; Terrien et al., 2017; Andreff, 2011)

o Corporate governance (Ma and Kurscheidt, 2019;

Schubert, 2014; Winand and Anagnostopoulos, 2019)

o Mainly the English, Spanish, Italian, German and

French men's leagues

Source(s): Own elaboration
Influence of stakeholders' perception on value

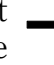


other two, are, for instance, measures of the effectiveness and performance of processes, human resources management, process management and measures of intellectual capital. From the standpoint of viewing the finances of enterprises and financial reporting, the primary drivers of change in enterprise value which directly concern business performance are the enterprise value drivers (Black et al., 1998). These drivers do not themselves create value but are its definition, valuation and measure, a secondary effect of antecedents such as key activities, resources, processes and relations.

To understand enterprise value creation, a value analysis matrix was elaborated (Figure 2). The key step is to link the antecedents, factors $(\mathrm{F})$ such as relational capital and processes, to specific value measures $(\mathrm{Y})$. These measures are associated with stakeholder benefits. At the level of measures $(\mathrm{Y})$, quantifiable information begins to surface, making it reasonable to assign change directions and change magnitudes to them. Chosen drivers measure the value of specific types of benefits expected by stakeholders that therefore should be properly assigned to them (V). In Figure 2, chosen factors can interfere with different measures which can interfere with different benefits perceptions. It shows that there is no one clear way to catch the value for all possible stakeholders' expectations. Performance of value

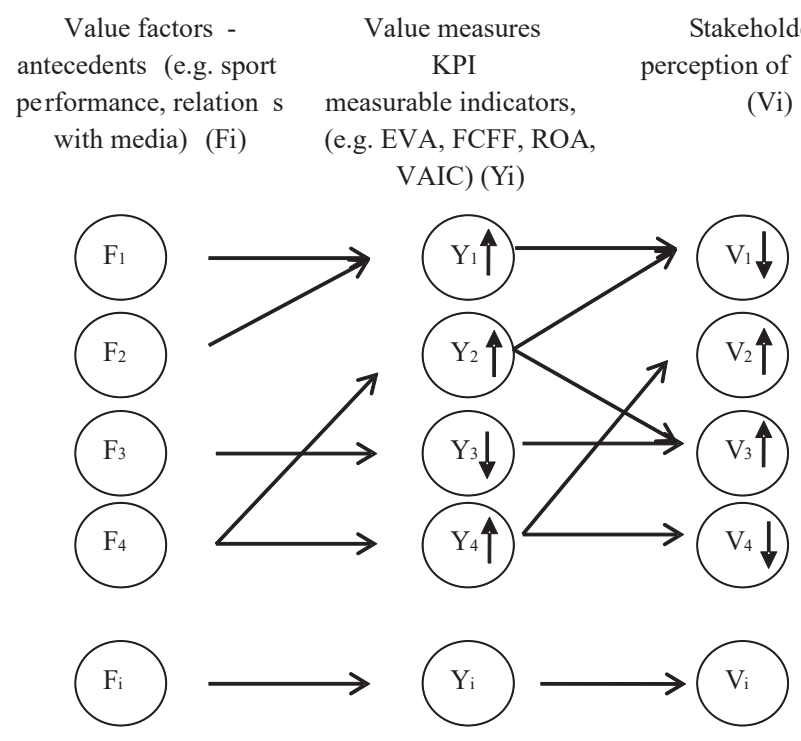

Figure 2.

A value analysis matrix

\section{Key:}

$\mathrm{Fi}$ - value factors - antecedents

Yi - value drivers - indicators, value measures, key performance indicators

$\mathrm{Vi}$ - benefits or value expected from the stakeholder perspective

$\mathrm{i}$ - can achieve any number dependent of numbers of factors (Fi), value measures (Yi) or benefit perceptions (Vi)

$\nearrow$ - influence

$\uparrow$ - upward trend direction (increase)

$\downarrow$ - downward trend direction (decrease)

Source(s): Own elaboration 
factor F4 can be measured by methods: Y2, Y4 and Y4 methods cover only V2 and V4 stakeholders' benefits expectations. Cases 1 to 4 are just simplification.

Application of the proper method for conducting a performance measurement must be based on the process of creating benefits and value for the stakeholders (Figure 1).
Influence of stakeholders' perception on value

\section{Research process}

\subsection{Problem and goals}

While identifying the vital factors impacting the value of football clubs, it must be noted that value is essentially the bundle of benefits that the stakeholders will be receiving. The clubs themselves may show a negative value from the financial perspective of the owner, but the benefits received by all stakeholders are not necessarily presented as part of clubs' financial results.

The research problem addresses the question of whether football sports clubs' value factors are so unique that the traditional valuation methods do not include the key factors which affect the value of these clubs from the stakeholders' perspective.

The objectives of the paper are identification and classification the factors impacting the value of men's football clubs in Poland while also discussing how these factors can affect the measurement of value. In order to accomplish the research goals, the following questions were posed:

(1) What are the different economic, social and infrastructural factors which create the value of football sports clubs?

(2) What is the respective importance of these different factors from the stakeholders' perspective?

(3) Which current valuation method is the most suitable for application to football clubs?

No clear approach to this problem can be identified in the literature. The research conducted thus far helps determine which existing enterprise valuation methods are most suitable for football clubs, which factors are not taken into account by these methods and hence how they can be modified. The research presented in this paper seeks to expand what is known about the factors shaping the value of football sports clubs and to begin the discussion on performance measurement indicators that ensure the sustainability of stakeholder relationships is maintained.

\subsection{Methodology}

The interview method was chosen due to the need to acquire new information about the financial and non-financial factors that affect football clubs and determine their success.

Research methods were selected to suit the mixed approach, which may produce more extensive results. This approach provided the researchers with additional information that helped identify the key value factors. The outcomes of the case analysis and the interview results are triangulated in the discussion section.

This paper relies first on the qualitative research approach because the goal is to understand, identify and classify the factors creating the value of football sports clubs from the stakeholders' perspective. The approach chosen for the research leads to a more holistic understanding of value creation and measurement within its context, noting that a similar approach was taken by accounting and performance management researchers (Llewelyn, 2003; Hopper and Hoque, 2006). As a result, the paper develops methods related to enterprise valuation theory and the theory of enterprise value management based on the case of sports clubs, which determines the cognitive nature of the research. 
A case study analysis of football clubs is undertaken in the research because this method helps describe, explain and generalise the phenomenon under study (Yin, 2004). The purpose of employing this method is to assess the current valuation methods from the standpoint of football club value measurement and to determine which valuation methods most accurately reflect the value of a club. This approach was chosen since knowledge concerning football club value measurement is still in its early stages, which justifies the use of this research method as argued by Yin (2004). Poland was selected as a representative large country in CEE which may be considered as an emerging economy. Football in Poland is regarded as a national sports. Although Polish football clubs are still not successful in European competitions, they appear as research objects in management, finance and economic science. The clubs selected for the case analysis (Tables A1 and A2 in Appendix) are those which participated in the Ekstraklasa league (the highest-level men's football league) for at least two seasons during the 2010-2014 period, and which in that period had at least three years of continuous financial data reporting in a constant income statement-company balance sheet format. The data were collected from databases such as EMIS (emerging markets research, data and news), Amadeus and also directly from the football clubs' financial statements. The data were used to calculate the chosen financial indicators. In order to compare financial indicators, the mean indicator and the maximum and minimum value ranges of the selected ratios were considered. The date range was chosen in order to include UEFA Euro 2012 which took place in Poland and the changes made during that time due to organising a football tournament at such a level. Ultimately, 11 clubs from Ekstraklasa that met the criteria were chosen for the research (the total number of clubs is 16 , and it is noted that, except for one club listed on the NewConnect stock exchange, they are unlisted joint-stock companies). It must be stressed that the choice of clubs is also affected by the fact that every season in the highest league, the two clubs ranked lowest in Ekstraklasa are demoted to the lower league, with their spots being filled by two clubs advancing from that league. For this reason, the clubs selected for the research are those which played in the highest league for most seasons in the examined period.

The case study analysis is primarily based on financial analysis and an analysis of information contained in financial statements and reports on the researched clubs published by professional consulting institutions. The study relies on data from three yearly reporting periods of the chosen clubs. However, since during the period under study some clubs changed their reporting periods from the calendar year to the season year (from the start to the end of the season), the data were converted to comparable values (a few of reports were disclosed for $1 \frac{1}{2}$.-year operations and income statement data needed to be modified annually for comparison). Further, the sports business is characterised by one-off occurrences, such as the substantial sales value of a player. In order to reduce such effects in the analysis, the study relied on average data from three reporting periods. The case analysis which is conducted contributes to the answers of the first and second research questions. In order to describe the sports business, the chosen performance indicators are compared. Data are collected after the football league transformation period, and all possible cases in the highest football league are taken into account. This part of the research complements the interviews that were performed.

In order to identify the key factors influencing the value of football clubs (first research question) (Table 2), interviews with stakeholders were carried out. Participant observation was also used in order to classify specific stakeholders of football clubs and their expectations of clubs, where observations were made by the authors during workshops, meetings and conferences for sports managers, coaches, players and sports activists. Moreover, observations were made while visiting football clubs and municipal offices and in meetings between fan representatives, municipal employees, representatives of clubs and members of a football federations' committee. The observations took place between 2013 and 


\begin{tabular}{|c|c|c|c|c|c|c|c|}
\hline $\begin{array}{l}\text { Sorted } \\
\text { by } \\
\text { weight }\end{array}$ & Factors & $\begin{array}{l}\text { Weight } \\
(\%)\end{array}$ & $\begin{array}{l}\text { Financial } \\
\text { factors }\end{array}$ & $\begin{array}{l}\text { Players } \\
\text { related } \\
\text { factors }\end{array}$ & $\begin{array}{c}\text { Intellectual } \\
\text { capital factors }\end{array}$ & $\begin{array}{l}\text { Sports } \\
\text { performance } \\
\text { factors }\end{array}$ & $\begin{array}{c}\text { Influence of } \\
\text { stakeholders } \\
\text { perception on }\end{array}$ \\
\hline 1 & Player value & 6.04 & + & + & + & + & value \\
\hline 2 & Revenue stability & 5.63 & + & & & & \\
\hline 3 & Liquidity & 5.53 & + & & & & \\
\hline 4 & Skill level of players & 5.48 & & + & + & + & \\
\hline 5 & Proper club strategy & 5.19 & & & + & & \\
\hline 6 & Sports level & 5.06 & & + & & + & \\
\hline 7 & $\begin{array}{l}\text { Cooperation with } \\
\text { local authorities }\end{array}$ & 4.47 & & & + & & \\
\hline 8 & $\begin{array}{l}\text { Competencies of } \\
\text { managerial staff }\end{array}$ & 4.40 & & & + & & \\
\hline 9 & $\begin{array}{l}\text { Revenue from sales } \\
\text { of media rights }\end{array}$ & 4.34 & + & & & & \\
\hline 10 & Coaching staff & 4.32 & & & + & + & \\
\hline 11 & Sponsor contracts & 4.27 & + & & & & \\
\hline 12 & Media attraction & 3.88 & & & + & & \\
\hline 13 & Brand recognition & 3.83 & & & + & & \\
\hline 14 & $\begin{array}{l}\text { Condition of } \\
\text { infrastructure }\end{array}$ & 3.75 & & & & & \\
\hline 15 & $\begin{array}{l}\text { Development } \\
\text { expenses (own } \\
\text { academy) }\end{array}$ & 3.47 & + & + & + & & \\
\hline 16 & Match attendance & 3.39 & & & & & \\
\hline 17 & $\begin{array}{l}\text { Organisational } \\
\text { structure } \\
\text { effectiveness }\end{array}$ & 3.37 & & & + & & \\
\hline 18 & $\begin{array}{l}\text { Participation in } \\
\text { European } \\
\text { tournaments }\end{array}$ & 3.19 & & & & + & \\
\hline 19 & $\begin{array}{l}\text { Internal } \\
\text { communication in } \\
\text { the club }\end{array}$ & 3.03 & & & + & & \\
\hline 20 & Transfer policy & 2.88 & & + & + & + & \\
\hline 21 & Club reputation & 2.80 & & & + & & \\
\hline 22 & $\begin{array}{l}\text { Corporate } \\
\text { governance }\end{array}$ & 2.70 & & & + & & \\
\hline 23 & $\begin{array}{l}\text { Communication } \\
\text { with environment }\end{array}$ & 2.37 & & & + & & \\
\hline 24 & Customer loyalty & 2.26 & & & + & & \\
\hline 25 & Location & 1.70 & & & & & \\
\hline 26 & Tradition & 1.59 & & & + & & \\
\hline 27 & $\begin{array}{l}\text { Participation of } \\
\text { foreign players }\end{array}$ & 1.05 & & + & & + & \\
\hline $\begin{array}{l}\text { Sum of } \\
\text { and in a }\end{array}$ & $\begin{array}{l}\text { ctors' weights in total } \\
\text { hosen category (in \%) }\end{array}$ & 100.00 & 29.28 & 23.98 & 62.08 & 28.02 & \\
\hline \multicolumn{7}{|c|}{$\begin{array}{l}\text { Note(s): + Factor was assigned to the given factor group (a single factor may belong to more than one } \\
\text { category) } \\
\text { Source(s): Own elaboration }\end{array}$} & $\begin{array}{l}\text { Table } 2 . \\
\text { Key success factors of } \\
\text { football clubs in Poland }\end{array}$ \\
\hline
\end{tabular}

2015. These methods were chosen due to the need to acquire new information, more specifically, the research aimed to gather information about the economic and non-economic factors influencing football clubs' value and their performance. These observations were realised to prepare further interviews. During and after observations, preliminary interviews 
were performed, which allowed a tentative list of success factors for football clubs to be prepared for final interview.

The analysis of the key value factors was performed on the basis of interviews carried out by the authors of the paper with representatives of the main stakeholder groups in a chosen football club. The method implemented stakeholders' perspective into value measurement. The interviewed individuals were employed by, worked with or were a representative of an institution associated with the football club. Ten individuals held the following positions and roles: manager, coach, local sponsor, alderman, municipal employee in the department of sports and health promotion, media representative, player, fan and local citizen (non-active fan) and football association representative. The interviews were conducted between 2015 and 2018. The data were collected in the form of notes and memos. The collected information was reduced, displayed and classified in a way to help answer the research questions (first and second) as recommended in a qualitative approach (Walliman, 2011; Taylor and Bogdan, 1998). The research was carried out on a sample of 10 individuals from a single football club whose characteristics were shared by most of the football clubs in the case analysis (ownership structure, fan activity, struggling with financial difficulties, size of the city, similar role in region as in other cases, close relationship with local government). The number of respondents is limited, which leads us to future further elaboration and validation needs of obtained results. There is also a risk of subjective perspective of respondents. In order to partially limit the risk, we have chosen one of the most representative football club on analysed market. The interviews enabled the success factors to be ranked from the most to the least important in the perspective of the interviewed individual, who had to rank all 27 factors from most to least important. The interviewer's role was merely to help the interviewee understand some of the unclear factors in case. Yet it is crucial to remember that the method used has certain limitations. The researcher interferes in the interview by giving an introduction to and explaining the purposes of the interview. Moreover, the interviewee is subject to various factors at the same time, which may affect their judgement, such as recent events in their life and the opinions of others. As a consequence, the interview results represent a certain perspective on viewing the problem at a given point in time. The material became saturated after all of the main stakeholders were included, allowing the interview process to be concluded. The material was gathered, the factors were grouped and merged into common categories and then recalculated so as to present weights using the rank-sum procedure. The factors were sorted according to the scores given in the interview (Table 2). The factors were ranked from 27 (the lowest) to 1 (the highest). In order to compute the weights for each factor, the rank score of each response was reversed. The value of the obtained score for all responses was summed up for each factor and divided by the total value of the scores. The result is the weight of each factor. In this method, weights are the individual ranks normalised by dividing by the sum of the ranks (Stillwell et al., 1981).

\section{The financial side of the football business in Poland}

The aim of this section is to present financial situation of Polish men's football clubs in order to open the discussion on the third research question (Tables A1 and A2 in Appendix). Seven of the 11 analysed clubs are directly or indirectly linked or owned by public institutions. It is also observed that the chosen clubs in this group are characterised by negative equity capital, revealing their poor financial results. Local government units support and finance sports clubs, motivating them by way of the public relations (PR) of the local government and promotion of the region. Only four of the analysed clubs show a debt level below $100 \%$ of their total asset value. Analysis of the liabilities shows that the mean coefficient value of the debt ratio indicator in three reporting periods during the period 2010-2014 reaches 208\% of the asset value among the researched clubs (Table A1 in Appendix). 
Despite the difficult financial situation, most clubs do not go bankrupt, which is another aspect to be considered with respect to the approach to measuring the value of these clubs. To illustrate the effects of applying indicators of financial assessment, discriminant measures used in assessing the risk of bankruptcy were also applied (Table A2 in Appendix). Almost all of the clubs are within the insolvency risk zone.

Due to the negative equity, it is hard to find the optimal capital structure value (Giner and Reverte, 2001). Additionally, interviews with stakeholders showed that in most cases Polish football clubs take a loan from their owners, and, when they are unable to service the debt, it is converted into equity, which raises serious questions about how to interpret the financial information on the capital structure found on the balance sheet. This also limits the use of value measurement methods that rely on profit and loss results. Concurrently, it raises a question about the possibility of using an income-based valuation and methods based on value added and making use of the weighted average cost of capital (WACC). This study investigates how many cases have a positive value of calculated WACC without estimation of the market value of equity (privately held companies). The calculation showed that 6 of the 11 clubs under study reveal a positive WACC (equity calculated based on book value), with the 5 remaining cases being negative. On the other hand, using marketised WACC (positive in most cases) for the EVA calculations still produced negative values of this indicator in all analysed cases (Table A1).

Football clubs are also specific in terms of financial information regarding their asset structure. Most of the researched clubs (with the sole exception of the Zagłebie Lubin club) do not have their own sports infrastructure and instead use facilities belonging to the local government. As a result, tangible fixed assets usually constitute a small share of the asset structure of football clubs. Among fixed assets, the most important are players acquired through transfers. Players are a key value factor of football clubs and hold the potential to create and increase club value (Markham, 2013; Perechuda, 2016; Kotáb and Scholleová, 2011).

Assets resulting from player transfers are key component of football clubs' overall assets (included in intangible assets) that is subject to depreciation, much like tangible fixed assets. Depreciation of player assets is an important part of the costs of a football club, and profits and losses on the sale or acquisition of players may significantly impact the financial results (Lozano and Gallego, 2011; Amir and Livne, 2005). Table A1 illustrates the average 3-year intangible assets share in the total assets of football clubs. The average level reaches $25 \%$ of the clubs' book value.

It is worth noting that a club's players are not necessarily players acquired through transfers. A club also has players who are alumni of the club, those who joined the club by free transfer since they were not under contract with any other club or those on loan from another club. Information regarding club alumni and players on loan is not visible in the data presented under intangible assets on the balance sheet. Such players may be identified through the profit and loss account, and on the payroll. Moreover, a club's main intangible resources also include the coaches and managers the club employs. In these cases, identifying them in the financial statement is also possible by looking at payroll expenses. This argues in favour of applying the intellectual capital valuation method as already concluded in other studies based on the football sector (Yasar et al., 2015; Perechuda, 2020; Shareef and Davey, 2005). This group of methods should be grounded on the assumption that wages constitute an investment in intellectual capital (VAIC method (Pulic, 1998)).

The level of salaries and their share in revenue may reveal a club's strategy. The average level in the researched clubs reaches $86 \%$ (Table A1). This means that, on average, $86 \%$ of sales revenue is appropriated for salaries, a significant portion of them being player salaries. It seems alarming that among the 11 examined clubs, 3 had salary levels near the level of the sales revenue achieved, and 1 club considerably exceeded that level.

When considering the above analysis, two conclusions come to mind:
Influence of stakeholders' perception on

value 
(1) Players that comprise $25 \%$ of total assets absorb over $86 \%$ of club-generated sales revenue for their functioning, and

(2) Players affecting revenue, cost and balance sheet items should be taken into account in the processes of measuring the value of a club and constructing a performance management system.

The analyses of stakeholders and football club financial data indicate that investors who decide to finance a football club in Poland have no reason to expect that the club will generate a capital return on the capital invested. The benefits received by the investors, many of which are local government units, are different from profits. Private investors also contribute their capital expenditure to the club, often acting as a sponsor and expecting to build their personal image or the image of their business (Garcia del Barrio et al., 2016). This amounts to the club generating intangible benefits for its investors. Therefore, the application of value drivers based on generating cash flows to the investors, along with the use of methods relying on the cost of capital, is not justified. What is more, it is necessary to bear in mind that the measurement method should take all key stakeholders into account.

\section{Value factors - interview results}

The main objective of the study was to identify, classify and grade the factors which influence football club value. This is needed to help define the correct attributes that measure the achievements and value of a football club (Figure 2). In the paper, understanding of value factors is in line with Freeman and McVea's (2001) work. Therefore, key success factors are the specific areas of enterprise activity to which managers should focus their attention when aiming to maximise value for the stakeholders. Consequently, they are also the key value factors.

The authors specified four categories of success factors (Table 2) that overlap each other (e.g. player value is in the category of factors related to players and in the category of factors related to intellectual capital). There are factors related to finance (e.g. revenue stability, revenue from sales of media rights), players (e.g. sports level, skills), intellectual capital (e.g. media attraction, relational resources concerning local government units) and sports performance. These four categories are consistent with the literature review (Table 1) which listed some research groups concerned with the performance of sports organisations. The chosen stakeholders' perspective also determined the listed categories of factors. Financial factors were determined by the perspective of shareholders, financing institutions such as local governments and the football association. Moreover, much of the research in the literature review deals with the financial aspects of sports (Table 1). Factors related to players were determined by the stakeholders' perspective: the players themselves, media, fans, management, coaches. There is also a lot of significant research about the performance, valuation and transfer of football players (Table 1). Factors related to intellectual capital (IC) were grouped in view of the social and relational capital created by the football club network (Figure 1) which in previous research is called collaborative value co-creation (Castro-Martinez and Jackson, 2014). Factors related with IC were grouped by reason of the share of intangible assets in football clubs (Table A1 in Appendix), social and media activity (such as CSR actions (Roşca, 2014)), physical and sports education, fan relations or brand creation (Table 1), human resources topics (Table 1) and the expectations of stakeholders such as local government and private sponsors (Figure 1). The last category is crucial because it relates to the sports performance of leagues, clubs, teams and players. It is these aspects which are fundamental to the building of any value in sports organisations and make this business so different from others (Szymanski and Kuypers, 1999; Carlsson-Wall et al., 2016). 
The research on the key success factors and values in football clubs has demonstrated and confirmed the previous assumptions, namely, that the key factor determining the business performance of a club is its players. Their value is at the top of the hierarchy of success factors. The weighted sum of all success factors related to players, that is, player value, transfer policy, the participation of foreign players, training of junior players, sports level of the team and the skill level of players, amounts to over $24 \%$. In addition, the structure of the top ten key success factors reveals three factors are related to the players (Table 2). It is noted that the weighted sum of the first ten key success factors exceeds $50 \%$. It may also be observed that as many as four factors from the financial area of a club's activity are listed in the top 10: player value, revenue stability, liquidity and revenue from sales of media rights (chiefly broadcasting rights). On the other hand, all the factors from the financial area have a total weight of $29 \%$, thereby confirming the intuitive assumption of Senaux (2008) that if professional sports clubs appear to be badly run, it may well be because the financial result is neither the unique nor necessarily the prime objective of the various stakeholders and that some of these stakeholders may be favoured at the expense of others. Such behaviour could threaten the organisation's survival in the long run as seen earlier in this paper (see Table A1 in Appendix). Among the key success factors, it can be observed that approximately $62 \%$ of the weight is assigned to factors related to intellectual capital.

Three aspects which strongly determine the business performance of sports clubs are worth noting:

(1) Intellectual capital. In this category, the key success factors are credited with a high share of all classified factors. Human resources, players, coaches, managers and relational resources including relationships with local government units are worth mentioning in this category. With regard to human resources such as coaches and managers, prior literature also emphasises their prominent role in affecting football club value and is highlighted not only in studies on the main Western European football leagues (Shareef and Davey, 2005; Bell et al., 2013; Risaliti and Verona, 2012) but also in studies on Eastern European leagues (Wyszynski, 2016; Roșca, 2012, 2014).

(2) Intellectual capital includes an important group of factors associated with players (the sum of weights is approximately $24 \%$ ). At the same time, the share of intangible assets disclosed on the balance sheet is 25\% (Table A1 in Appendix).

(3) Financial factors, when considered in terms of the concept of value creation, are mostly value drivers (revenue stability, liquidity) and are a secondary element with respect to the factors of value creation. Factors related with intellectual capital are the most important factors for success; however, success based on intellectual capital is only possible if financial situation allows it.

Moreover, complementary information includes the share of factors related to sports performance, which achieved the level of $28 \%$ (Table 2). It supports the Senaux's (2008) and Terrien et al.'s (2017) statement that sports clubs are highly focused on sports results. At the same time, the level is not high enough to show that sports results are the main factor in value creation, although it is a rather significant factor. Results need further elaboration mostly on validation of obtained weights in Table 2 . The classification of the key value factors may be used in future research to combine the proper value measurement method with each group of value factors. However, first of all, it is necessary to discuss valuation methods in the context of these key value factors and characteristics of the sector.
Influence of stakeholders' perception on value 


\section{Discussion on valuation methods}

Discussion on valuation methods is achieved by triangulating (Hopper and Hoque, 2006) all of the data collected and established during the research. It is worth mentioning that the obtained data pertain to the Polish men's football league and the findings need further research in order to be transferable to other countries. In other Eastern European countries, additional verification of the key value factors by interviews or a survey is needed. The analysis of valuation methods leads to a summary of the answers to three research questions:

(1) What are the different economic, social and infrastructural factors which create the value of football sports clubs?

(2) What is the respective importance of these different factors from the stakeholders' perspective?

(3) Which current valuation method is the most suitable for application to football clubs?

The current literature usually mentions three main groups of business valuation methods (Fernandez, 2017). Table 3 presents a concise overview of these methods while commenting on what these methods do not take into account with regard to value creation factors in sports clubs.

As shown in Table 3, the income method group may have very limited application in the case of football clubs. Greater application potential may be found in asset-based methods. The limitations arise from the lack of UEFA Financial Fair Play (FFP) regulation effects and the soft budget constraint (Andreff, 2015; Storm, 2012; Storm and Nielsen, 2012) because companies struggle year after year with financing. Although analysed sample of financial data was limited till 2014, more recent paper still disclosed bad financial health of men's football clubs in Poland after UEFA FFP implementation (Wyszyński, 2021).

Other valuation methods exist apart from the three main groups of valuation methods. For instance, there are mixed methods which are the result of combining the advantages of the

\begin{tabular}{ll}
\hline Types & Specification of the method \\
\hline Income- & It does not take all key stakeholders into account. Clubs have liquidity difficulties, rendering \\
based & them unable to generate free cash flow for their creditors and owners. Another difficulty is \\
& negative equity value. Also, the researched clubs are not listed on the stock exchange. On the \\
& other hand, the fact that a poor financial situation is a constant element of club functioning, \\
and yet clubs continue to function and do not go bankrupt, allows the conclusion that there are \\
stakeholders which accrue certain benefits from their functioning, but these benefits cannot be \\
valued only by income-based methods. The financial factors are classified by stakeholders but \\
achieved $29 \%$ of overall importance (Table 2) \\
Among asset-based methods, the net adjusted asset method provides the greatest utility for \\
football clubs. It follows that the player value should be adjusted and valued in the market \\
value of these players, as suggested by Lozano and Gallego (2011). This method allows the \\
inclusion of player value. However, players are only one part of a club's intellectual capital. \\
The total weights of the key success factors related to intellectual capital achieved $62 \%$ \\
(Table 2). The researched clubs do not go into liquidation despite their negative financial \\
results. The replacement method would be difficult to apply in the case of player registration \\
card valuation. There is another element worth mentioning concerning this method, namely, \\
that asset value can be significantly inflated if a club owns a stadium \\
The main issue of applying these methods in the case of football clubs is the lack of a liquid \\
market (Demir and Danis, 2011;Perechuda, 2016) or comparable transactions able to serve as a \\
reference
\end{tabular}

Table 3.

Discussion on the main valuation methods

Source(s): Own elaboration and based on Fernandez (2017), Brealey and Myers (2002), Damodaran (2012) 
asset-based and income-based methods. They build on the assumption that value is shaped not only by assets but also by the ability to generate income. However, relying on the profit or loss position is problematic for measuring club value as long as clubs produce losses year after year without going bankrupt and the profits are not what shareholders and other stakeholders expect (Terrien et al.,2017). Aside from the use of mixed methods, there are some unconventional methods that should be mentioned. These include all methods that cannot be classified in any of the groups mentioned previously. Among these methods, those that include emotional engagement (Zarzecki, 2010) or intellectual capital (Pulic, 1998) are interesting in the football club context and should certainly be considered when constructing a performance measurement method, as already noted in leagues such as the Turkish one (Yasar et al., 2015). The valuation of intellectual capital measures is often based on nonfinancial information. The outcome of the research corresponds to the study by Sievers et al. (2013) who discussed the usefulness of accounting information for investment purposes and highlighted non-financial information as evidence for gauging the overall valuation methods. In addition, Amir and Lev (1996) suggest that market value in the wireless sector (where intellectual capital is a key value factor) may be explained by non-financial indicators.

\section{Conclusion}

Identified and classified key value factors enable the management of football clubs to properly manage the stakeholder relationships and address the various stakeholder groups' economic, sports and social concerns. Discussion on valuation methods in section 6 is an input for future valuation method proposition which should include all most important value factors identified in the study.

Senaux (2008) and Terrien et al. (2017) state that professional football clubs in Europe can have different orientations (profit maximisation, utility maximisation under hard budget constraint, utility maximisation under soft budget constraint). It is a bit opposite to professional franchises in the USA which are organised with a view to maximising their economic efficiency. Utility maximisation is represented by the complex set of football clubs' goals, which are not always fully integrated, shared or defended by all club stakeholders, which was also found by Ma and Kurscheidt (2019). The research conducted answered the problem of interest marginalisation in a narrow stakeholder perspective. The paper focused on the notion of value factors and assumed that value measures should be selected to reflect broad stakeholder interests. Sanchez et al. (2017) argue that a company's objective is linked to maximising the capital invested by the owner(s). However, an investment decision is, like other human decisions, aimed at receiving satisfaction from the benefits that accrue. A higher return on investment means greater investor satisfaction; yet other rewards or emotional dividends may also increase satisfaction. Also, Sánchez (2012) discusses cases, such as satisfaction with participating in a family business, that involve satisfaction with the capacity to influence public opinion and political decisions. A similar situation is observed in football clubs from the stakeholders' perspective based on the present study.

In the paper, we discussed which performance and value measures should be used to measure value for the stakeholders of football clubs. Intellectual capital methods should definitely be relied on as part of measuring the performance of football clubs in Poland as well as in the wider CEE region. Besides, asset-based methods better reflect the financial situation of football clubs than income-based methods. This is true in particular when applying the method of adjusted net assets and estimating the balance-sheet-based value of players compared to their market value. It covers a broader group of key value factors. The above considerations recommend the use of the multivariate valuation method in accordance with a research previous research (Markham, 2013; Morrow, 1996; Lozano and Gallego, 2011). The present study provides a framework for research in other contexts, to be adapted to the
Influence of stakeholders' perception on

value 
characteristics of the latter. The paper's results answered a classic agency problem (Schubert, 2014) and delivered knowledge of how to include the interest of all the stakeholders in the valuation process. Therefore, the use of the multivariate valuation method should include key value factors identified in this paper. In addition, it is worth noting that, as long as the financial information contained in the financial statements is limited in use for a certain study, non-financial reporting and integrated reporting may deliver a wider range of information than mere financial data, to support the measurement of performance (Dumitru et al., 2017).

The paper paid special attention to the complex debates on stakeholder theory and its influence on the measurement of value. The research procedure which was applied may be replicated in other sectors characterised by the need for sustainable stakeholder relationships, such as social enterprises or non-governmental organisations.

\section{References}

Amir, E. and Lev, B. (1996), "Value-relevance of nonfinancial information: the wireless communications industry", Journal of Accounting and Economics, Vol. 22 Nos 1-3, pp. 3-30.

Amir, E. and Livne, G. (2005), "Accounting, valuation and duration of football player contracts", Journal of Business Finance and Accounting, Vol. 32 Nos 3-4, pp. 549-586.

Andreff, W. (2011), Contemporary Issues in Sports Economics: Participation and Professional Team Sports, Edward Elgar Publishing, Cheltenham and Northampton.

Andreff, W. (2015), "Governance of professional team sports clubs: agency problem and soft budget constraint", in Andreff, W. (Ed.), Disequilibrium Sports Economics: Competitive Imbalance and Budget Constraints, Edward Elgar, Cheltenham and Northampton, MA, pp. 175-227.

Bednarz, B. (2014), “Case study of a polish football club - KKS Lech Poznan, year 2009-2013”, in Knowledge, Economy, Society - Managing Organizations: Concepts and Their Applications, Cracow, pp. 53-60.

Behn, B.K. and Riley, R.A. Jr (1999), "Using nonfinancial information to predict financial performance: the case of the U.S. airline industry", Journal of Accounting, Auditing and Finance, Vol. 14 No. 1, pp. 29-56.

Bell, A.R., Brooks, C. and Markham, T. (2013), "Does managerial turnover affect football club share prices?", The IEB International Journal of Finance, Vol. 7, pp. 4-8.

Black, A., Wirght, P. and Bachman, J. (1998), In Search of Shareholder Value: Managing the Drivers of Performance, London.

Brealey, R.A. and Myers, S.C. (2002), Principles of Corporate Finance, 7th ed., McGraw-Hill, New York, NY.

Callejo, M.B. and Forcadell, F.J. (2006), "Real Madrid Football Club: a new model of business organization for sports clubs in Spain”, Global Business and Organizational Excellence, Vol. 26 No. 1, pp. 51-64.

Carlsson-Wall, M., Kraus, K. and Messner, M. (2016), "Performance measurement systems and the enactment of different institutional logics: insights from a football organization”, Management Accounting Research, Vol. 32, pp. 45-61.

Castro-Martinez, M.P. and Jackson, P.R. (2014), "Collaborative value co-creation in Community Sports Trusts at football clubs", Corporate Governance - An International Review, Vol. 11 No. 2, available at: http://ssrn.com/abstract $=2540364$ (accessed 20 November 2016).

Clarkson, M.B.E. (1995), "A stakeholder framework for analyzing and evaluating corporate social performance", The Academy of Management Review, Vol. 20 No. 1, pp. 92-117.

Cyfert, S. and Janicki, M. (2016), "Football clubs' business models - an attempt at a typology", Research on Enterprise in Modern Economy - Theory and Practice, Vol. 4, pp. 9-16.

Damodaran, A. (2012), Investment Valuation: Tools and Techniques for Determining the Value of Any Asset, 3rd ed., John Wiley \& Sons, New York. 
Demir, E. and Danis, H. (2011), "The effect of performance of soccer clubs on their stock prices: evidence from Turkey”, Emerging Markets Finance and Trade, Vol. 47 No. 4, pp. 58-70.

Dermit-Richard, N., Scelles, N. and Morrow, S. (2019), "French DNCG management control versus European UEFA financial fair play: a divergent conception of financial regulation objectives", Soccer and Society, Vol. 20 No. 3, pp. 408-430.

Dobson, S., Gerrard, B. and Howe, S. (2000), "The determination of transfer fees in English nonleague football”, Applied Economics, Vol. 32 No. 9, pp. 1145-1152.

Dumitru, M., Dyduch, J., Gușe, R.-G. and Krasodomska, J. (2017), "Corporate reporting practices in Poland and Romania - an ex-ante study to the new non-financial reporting European directive", Accounting in Europe, Vol. 14 No. 3, pp. 279-304.

Ferkins, L. and Shilbury, D. (2015), "The stakeholder Dilemma in sport governance: toward the notion of 'Stakeowner"', Journal of Sport Management, Vol. 29 No. 1, pp. 93-108.

Fernandez, P. (2017), Company Valuation Methods, available at: http://dx.doi.org/10.2139/ssrn.274973 (accessed 11 October 2017).

Freeman, R.E. and McVea, J. (2001), “A stakeholder approach to strategic management”, Darden Business School Working Paper No. 01-02, 2001, available at: http://ssrn.com/abstract=263511 (accessed 11 October 2017).

Garcia del Barrio, P., Ferreiro, B.M. and Foronda Lopez, A.L. (2016), "Media value in football", Merit report 15, Universidad Internacional de Catalunya, Barcelona.

Garcia del Barrio, P. and Pujol, F. (2013), "Sport talent, media value and equal prize policies in Tennis", Faculty Working Papers No. 01/13, School of Economics and Business Administration, University of Navarra, Pampelona.

Garcia-del-Barrio, P. (2018), "Media value methodology and global sport industries: football versus Formula One", International Journal of Sport Management and Marketing, Vol. 18 No. 3, pp. 241-266.

Garcia-del-Barrio, P. and Pujol, F. (2021), "Recruiting talent in a global sports market: appraisals of soccer players' transfer fees", Managerial Finance, Vol. 47 No. 6, pp. 789-811.

Gerke, A. and Wäsche, H. (2019), "Football, networks, and relationships", in Simon Chadwick, C.A., Parnell, D. and Widdop, P. (Eds), Routledge Handbook of Football Business and Management, Routledge, London, pp. 273-281, doi: 10.4324/9781351262804.

Giner, B. and Reverte, C. (2001), "Valuation implications of capital structure: a contextual approach", European Accounting Review, Vol. 10 No. 2, pp. 291-314.

Havran, Z. (2014), "Regional export efficiency in the market of football players", Theory, Methodology, Practice, Vol. 10 No. 2, p. 3.

Hopper, T.T.M. and Hoque, Z. (2006), "Triangulation approaches to accounting research", in Methodological Issues in Accounting Research: Theories, Methods and Issues Spiramus, London.

Iconomescu, T.W. (2017), "Top Romanian football clubs economic and sport performance analysis", Proceedings of the 29th International Business Information Management Association Conference, Vienna, pp. 3174-3186, Vol. Education Excellence and Innovation Management through Vision 2020: From Regional Development Sustainability to Global Economic Growth.

Ittner, C.D. and Larcker, D.F. (1998), "Are nonfinancial measures leading indicators of financial performance? An analysis of customer satisfaction", Journal of Accounting Research, Vol. 36, pp. 1-35.

Jabłoński, A. and Jabłoński, M. (2016), "Research on business models in their life cycle", Sustainability, Vol. 8 No. 5, p. 7.

Kisielińska, J. and Waszkowski, A. (2010), "Polish models for bankruptcy estimation and their validation”, Zeszyty Naukowe Szkoty Gtównej Gospodarstwa Wiejskiego w Warszawie. Ekonomika i Organizacja Gospodarki Zywnościowej, Vol. 82, pp. 17-31, (in Polish).
Influence of stakeholders' perception on value 
Kotáb, J. and Scholleová, H. (2011), "Evaluations in football player's contracts”, Proceedings: XIII IASE and III ESEA Conferences on Sports Economics, University of Economics, Prague, Czech, pp. 36-40.

Leifheit, N. and Follert, F. (2021), "Financial player valuation from the perspective of the club: the case of football", Managing Sport and Leisure. doi: 10.1080/23750472.2021.1944821.

Llewelyn, S. (2003), "What counts as theory in qualitative management and accounting research? Introducing five levels of theorizing", Accounting, Auditing and Accountability Journal, Vol. 16 No. 4, pp. 662-708.

Lozano, F.J.M. and Gallego, A.C. (2011), "Deficits of accounting in the valuation of rights to exploit the performance of professional players in football clubs. A case study", Journal of Management Control, Vol. 22, pp. 335-357.

Ma, Y. and Kurscheidt, M. (2019), "Governance of the Chinese Super League: a struggle between governmental control and market orientation", Sport, Business and Management, Vol. 9 No. 1, pp. 4-25.

Markham, T. (2013), "What is the optimal method to value a football club?”, ICMA Centre, available at: http://ssrn.com/abstract=2238265 (accessed 15 January 2016).

Morrow, S. (1996), "Football players as human assets. Measurement as the critical factor in asset recognition: a case study investigation", Journal of Human Resource Costing and Accounting, Vol. 1 No. 1, pp. 75-97.

Morrow, S. (1997), “Accounting for football players. Financial and accounting implications of 'Royal Club Liégois and Others V Bosman' for football in the United Kingdom”, Journal of Human Resource Costing and Accounting, Vol. 2 No. 1, pp. 55-71.

Nagar, V. and Rajan, M.V. (2001), "The revenue implications of financial and operational measures of product quality", The Accounting Review, Vol. 76 No. 4, pp. 495-513.

Novotny, J. and Sciklin, A. (2011), "Comparison of economics of top Czech and Western European professional team sports clubs", Ekonomika a Management, Vol. 2, pp. 5-16.

Parker, L.D. (2005), "Social and environmental accounting research: a view from the commentary box", Accounting, Auditing and Accountability Journal, Vol. 18 No. 6, pp. 824-860.

Pawlak, Z. and Smoleń, A. (2015), Strategies of Professional Sports Clubs in, Oficyna SGH, Warszawa, p. 2015, (in Polish).

Peng, Q., Skinner, J. and Houlihan, B. (2019), "An analysis of the Chinese football reform of 2015: why then and not earlier", International Journal of Sport Policy and Politics, Vol. 11 No. 1, pp. 1-18.

Perechuda, I. (2016), "Market value, book value and intellectual capital value in case of football clubs listed on stock exchange", Proceedings 8th International Scientific Conference Managing and Modelling of Financial Risks, VŠB-TU of Ostrava, Faculty of Economics, Department of Finance, Czech, 2016, Vol. 3, pp. 798-806.

Perechuda, I. (2020), "Intellectual capital determinants of football clubs in Europe", Polish Journal of Sport and Tourism, Vol. 27 No. 2, pp. 8-13.

Perrini, F. and Tencati, A. (2006), "Sustainability and stakeholder management: the need for new corporate performance evaluation and reporting systems", Business Strategy and Environment, Vol. 15 No. 5, pp. 296-308.

Plumley, D., Wilson, R. and Ramchandani, G.M. (2017), "Towards a model for measuring holistic performance of professional Football clubs", Soccer and Society, Vol. 18 No. 1, pp. 16-29.

Post, J.E., Preston, L.E. and Sachs, S. (2002), "Managing the extended enterprise: the new stakeholder view”, California Management Review, Vol. 45 No. 1, pp. 6-28.

Prigge, S. and Tegtmeier, L. (2020), "Football stocks: a new asset class attractive to institutional investors? Empirical results and impulses for researching investor motivations beyond return", Sport, Business and Management: An International Journal, Vol. 10 No. 4, pp. 471-494. 
Pulic, A. (1998), "Measuring the performance of intellectual potential in knowledge economy", Paper Presented at the 2nd World Congress of Measuring and Managing Intellectual Capital, Mc Master University, Hamilton.

Risaliti, G. and Verona, R. (2012), "Players' registration rights in the financial statements of the leading Italian clubs: a survey of Inter, Juventus, Lazio, Milan and Roma", Accounting, Auditing and Accountability Journal, Vol. 26 No. 1, pp. 16-47.

Roşca, V. (2012), "The financial contribution of international footballer trading to the Romanian football league and to the national economy", Theoretical and Applied Economics, Vol. 4 No. 4, pp. 145-166.

Roşca, V. (2014), "Web interfaces for e-CRM in sports: evidence from Romanian football”, Management and Marketing. Challenges for the Knowledge Society, Vol. 9 No. 1, pp. 27-46.

Sanchez, L.C. (2012), "Dividendo emocional: el papel de los accionistas en la responsabilidad empresarial", Revista de responsabilidad social de la empresa, Vol. 12, pp. 15-45, (in Spanish).

Sanchez, M., Luis, C., Barajas, A. and Sánchez-Fernández, P. (2017), "Does the agency theory play football?", Universia Business Review, Vol. 53, pp. 18-59.

Scelles, N., Helleu, B., Durand, C. and Bonnal, L. (2013), "Determinants of professional sports firm values in the United States and Europe: a comparison between sports over the period 20042011", International Journal of Sport Finance, Vol. 8 No. 4, pp. 280-293.

Scelles, N., Helleu, B., Durand, C. and Bonnal, L. (2016), "Professional sports firm values: bringing new determinants to the foreground? A study of European soccer, 2005-2013", Journal of Sports Economics, Vol. 17 No. 7, pp. 688-715.

Scelles, N., Helleu, B., Durand, C., Bonnal, L. and Morrow, S. (2017), "Explaining the number of social media fans for North American and European professional clubs with determinants of their financial value", International Journal of Financial Studies, Vol. 5 No. 4, p. 25.

Scelles, N., Szymanski, S. and Dermit-Richard, N. (2018), "Insolvency in French soccer: the case of payment failure", Journal of Sports Economics, Vol. 19 No. 5, pp. 603-624.

Schubert, M. (2014), "Potential agency problems in European club football? The case of UEFA Financial fair Play", Sport, Business and Management: An International Journal, Vol. 4 No. 4, pp. 336-350.

Senaux, B. (2008), “A stakeholder approach to football club governance", International Journal of Sport Management and Marketing, Vol. 4 No. 1, pp. 4-17.

Shareef, F. and Davey, H. (2005), "Accounting for intellectual capital: evidence from listed English football clubs", Journal of Applied Accounting Research, Vol. 7 No. 3, pp. 78-116.

Sievers, S., Mokwa, C.F. and Keienburg, G. (2013), "The relevance of financial versus non-financial information for the valuation of venture capitalbacked firms", European Accounting Review, Vol. 22 No. 3, pp. 467-511.

Simpson, A.V. (2010), “Analysts' use of non-financial information disclosures", Contemporary Accounting Research, Vol. 27 No. 1, pp. 249-288.

Stent, W. and Dowler, T. (2015), "Early assessments of the gap between integrated reporting and current corporate reporting", Meditari Accountancy Research, Vol. 23 No. 1, pp. 92-117.

Stillwell, W.G., Seaver, D.A. and Edwards, W. (1981), "A comparison of weight approximation techniques in multiattribute utility decision-making", Organizational Behavior and Human Performance, Vol. 28 No. 1, pp. 62-77.

Storm, R.K. (2012), "The need for regulating professional soccer in Europe: a soft budget constraint approach argument”, Sport, Business and Management: An International Journal, Vol. 2 No. 1, pp. 21-38.

Storm, R.K. and Nielsen, K. (2012), "Soft budget constraints in professional football", European Sport Management Quarterly, Vol. 12 No. 2, pp. 183-201.
Influence of stakeholders' perception on value

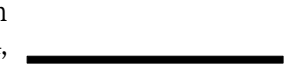


Szymanski, S. and Kuypers, T. (1999), Winners and Losers: The Business Strategy of Football, Viking Books, London.

Taylor, S.J. and Bogdan, R. (1998), Introduction to Qualitative Research Methods: A Guidebook and Resource, 3rd ed., John Wiley \& Sons, Hoboken, NJ, pp. 102-130.

Terrien, M. and Andreff, W. (2020), "Organisational efficiency of national football leagues in Europe", European Sport Management Quarterly, Vol. 20 No. 2, pp. 205-224, doi: 10.1080/16184742.2019. 1598455.

Terrien, M., Scelles, N., Morrow, S., Maltese, L. and Durand, C. (2017), "The win/profit maximization debate: strategic adaptations as the answer?”, Sport, Business and Management: An International Journal, Vol. 7 No. 2, pp. 121-140.

Thompson, A. and Parent, M.M. (2021), "Understanding the impact of radical change on the effectiveness of national-level sport organizations: a multi-stakeholder perspective", Sport Management Review, Vol. 24 No. 1, pp. 1-23.

Trueman, B., Wong, F.M.H. and Zhang, X.-J. (2000), "The eyeballs have it: searching for the value in internet stocks", Journal of Accounting Research, Vol. 38, pp. 137-162.

Trueman, B., Wong, F.M.H. and Zhang, X.-J. (2001), "Back to basics: forecasting the revenues of internet firms", Review of Accounting Studies, Vol. 6, pp. 305-329.

Valenti, M., Scelles, N. and Morrow, S. (2018), "Women's football studies: an integrative review”, Sport, Business and Management, Vol. 8 No. 5, pp. 511-528.

Wagner, F., Preuss, H. and Könecke, T. (2021), “A central element of Europe’s football ecosystem: competitive intensity in the big five", Sustainability, Vol. 13 No. 6, p. 3097.

Walliman, N. (2011), Research Methods: The Basics, Routledge, New York.

Winand, M. and Anagnostopoulos, C. (2019), Research Handbook on Sport Governance, Edward Elgar Publishing, Oxford.

Woratschek, H., Horbel, C. and Popp, B. (2014), "The sport value framework-a new fundamental logic for analyses in sport management", European Sport Management Quarterly, Vol. 14 No. 1, pp. 6-24.

Wyszynski, A. (2016), "Efficiency of football clubs in Poland”, Olsztyn Economic Journal, Vol. 11 No. 1, pp. 59-72.

Wyszyński, A. (2021), "Insolvency of professional football clubs”, Ekonomista, Vol. 1, pp. 142-166.

Yasar, N.N., Isik, M. and Calisir, F. (2015), "Intellectual capital efficiency: the case of football clubs", Procedia - Social and Behavioral Sciences, Vol. 207, pp. 354-362.

Yin, R.K. (2004), Case Study Research: Design and Methods (Applied Social Research Methods), Sage, London and Singapore.

Zarzecki, D. (2010), "Valuing internet companies. Selected issues", Folia Oeconomica Stetinensia, Vol. 9 No. 1, pp. 105-120. 


\section{Appendices}

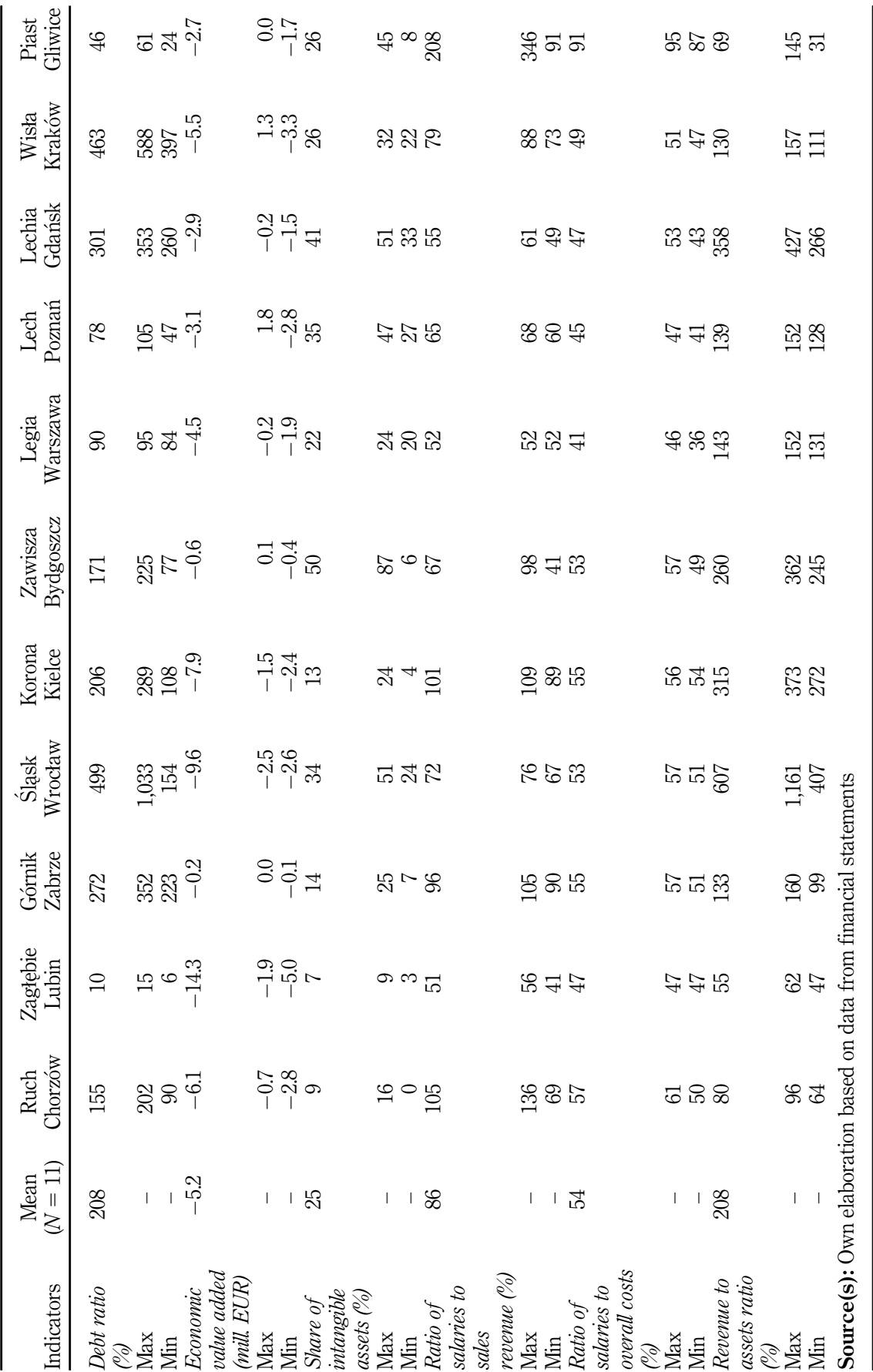

Influence of stakeholders' perception on value
Table A1.

Average values of chosen indicators from three reporting periods in the period 2010 2014 with maximum and minimum value 


\section{SBM}

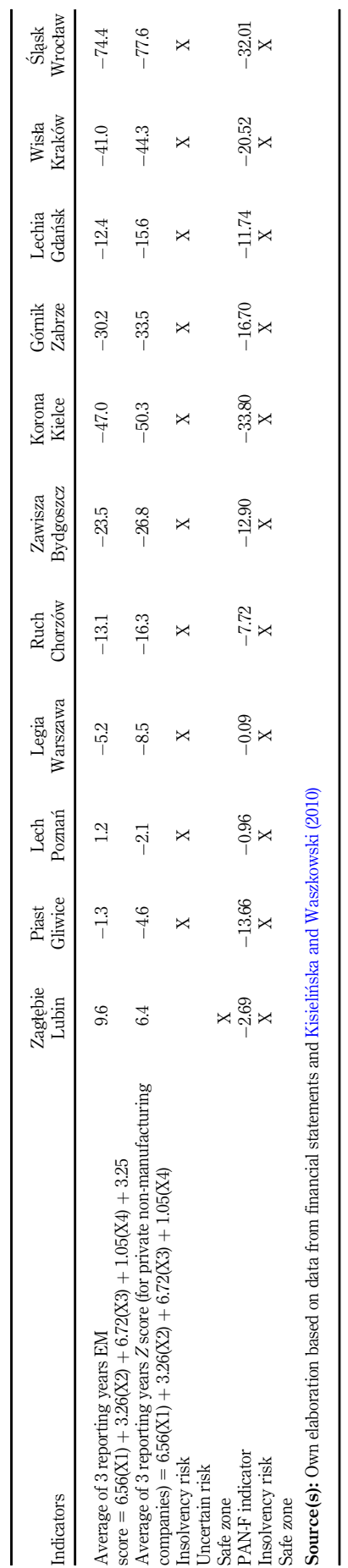

Table A2.

Bankruptcy risk Altman and PAN-F indicators, average values from three reporting periods in the period 2010$2014(n=33)$ 
CEE

Central and Eastern Europe

KPI Key performance indicators

EVA Economic value added

MVA Market value added

SVA Shareholders value added

CSR Corporate social responsibility

EPL English Premier League

FCF Free cash flow

ROA Return on assets

VAIC Value added intellectual coefficient

UEFA European Football Championships

Euro

PAN-F Discrimination indicator elaborated by the Polish Academy of Science

WACC Weighted average cost of capital

IC Intellectual capital

EM score Emerging market score Altman formula for determining whether a company in emerging markets is headed for bankruptcy

$Z$ score The Altman $Z$-score formula for determining whether a company, notably in the manufacturing space, is headed for bankruptcy

Source(s): Own elaboration
Influence of stakeholders' perception on value

Table A3.

Explanation of the variables and abbreviations

\section{Corresponding author}

Igor Perechuda can be contacted at: igor.perechuda@uj.edu.pl

For instructions on how to order reprints of this article, please visit our website:

www.emeraldgrouppublishing.com/licensing/reprints.htm

Or contact us for further details: permissions@emeraldinsight.com 